\begin{tabular}{c|cc}
\hline & & \\
& International Research Journal of Obstetrics and Gynecology & \\
\hline
\end{tabular}

\title{
Relation between pregnant women and the Brazilian Unified Health System (SUS): Screening and diagnosis of GDM
}

\section{Matheus Alves Siqueira de Assunção ${ }^{1 *}$, Francisco Henrique da Silva ${ }^{2}$, Aline Fernanda Carneiro Cardoso ${ }^{3}$, Evandro Valentim da Silva ${ }^{4}$, Hellencléia Pereira Cunha ${ }^{3}$, Fálba Bernadete Ramos dos Anjos ${ }^{2}$}

${ }^{1}$ Department of Histology and Embryology, Federal University of Pernambuco, Recife, Pernambuco, Brazil

${ }^{2}$ Department of Biochemistry, Federal University of Pernambuco, Recife, Pernambuco, Brazil

${ }^{3}$ Graduada em Farmácia pela Federal University of Pernambuco, Recife, Pernambuco, Brazil

${ }^{4}$ Clinical Hospital, Federal University of Pernambuco, Recife, Pernambuco, Brazil

\section{ABSTRACT}

The existence of a complex health system is capable of providing the necessary care for the mother and mother, but the levels of complexity of this treatment vary according to the need and severity of the situation in which the pregnant woman is ebcibtra. From this perspective, this chapter will address the relationship between pregnant women and the Brazilian Unified Health System, as well as the care and diagnosis of Gestational Diabetes Mellitus.

Keywords: SUS, Complexity, Treatment, Diabetes
*Correspondence to Author:

Matheus Alves Siqueira de Assunção

Department of Histology and Embryology, Federal University of Pernambuco, Recife, Pernambuco, Brazil

How to cite this article:

Matheus Alves Siqueira de Assunção, Francisco Henrique da Silva, Aline Fernanda Carneiro Cardoso, Evandro Valentim da Silva, Hellencléia Pereira Cunha, Fálba Bernadete Ramos dos Anjos. Relation between pregnant women and the Brazilian Unified Health System (SUS): Screening and diagnosis of GDM.International Research Journal of Obstetrics and Gynecology, 2020,3:35.

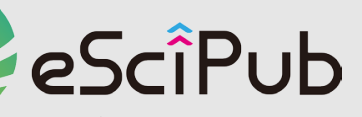

eSciPub LLC, Houston, TX USA. Website: https://escipub.com/ 


\section{Introduction}

In 2016, the World Health Organization (WHO) organized recommendations to improve the quality of prenatal care, considering the importance of medical care for gestational development. In this context, the organization recalls that clinical monitoring enables the detection and prevention of diseases, as well as counseling on healthy lifestyle and family planning. ${ }^{18}$.

Prenatal care is the starting point for a healthy birth, according to the Ministry of Health, with the requirement that favors the physical, emotional and social monitoring throughout the pregnancy process, since it guides the professionals involved in this screening prenatal care to define the conditions in which the mother is, reflecting the healthy habits developed during this phase of life ${ }^{5}$.

Ordinance 569, dated June 1, 2000, says that prenatal care must be provided free of charge by the Municipal Health Department from the first stage of pregnancy. It is important that through prenatal consultations, pregnant women are able to maintain adequate and controlled glycemic levels, in order to prevent fetal malformations and other complications in pregnancy ${ }^{12}$.

Gestational Diabetes Mellitus (GDM) is considered the most common metabolic problem in pregnancy ${ }^{8}$ and its prevalence can vary from 1 to $14 \% 1$ - studies with the Brazilian population have shown prevalences of GDM ranging between 2.9 and $6.6 \%$, 14,24 , and may trigger various adverse effects for the mother and the fetus ${ }^{3}$.

Thus, pregnant women with diabetes should be referred to Secondary Care Centers, and those diagnosed with pre-gestational diabetes should be referred to Tertiary Care Centers for evaluation by a multidisciplinary team, depending on the need and the severity of the case. Pregnant women diagnosed with Diabetes Mellitus should always be monitored jointly by the primary care team and the high-risk ${ }^{10}$ prenatal team according to the level of complexity defined by the Brazilian Unified Health System (SUS)(Table 1).

Table 1: Levels of complexity of the activities provided by the hospital.

\begin{tabular}{l|l}
\hline LEVELS OF COMPLEXITY OF THE ACTIVITIES PROVIDED BY THE HOSPITAL UNIT \\
\hline Primary attention & $\begin{array}{l}\text { It consists of the Basic Health Units (BHU), the Community Health Agents (CHA), } \\
\text { the Family Health Team (ESF) and the Family Health Support Center (FHSC). }\end{array}$ \\
\hline $\begin{array}{l}\text { Formed by specialized services on an outpatient and hospital level, with } \\
\text { intermediate technological density between primary and tertiary care, historically } \\
\text { interpreted as medium complexity procedures. This level includes specialized } \\
\text { medical services, diagnostic, therapeutic support and urgent and emergency } \\
\text { care. }\end{array}$ & $\begin{array}{l}\text { Designates the set of therapies and procedures of high specialization. It also } \\
\text { organizes procedures involving high technology and / or high cost, such as } \\
\text { oncology, cardiology, ophthalmology, transplants, high-risk delivery, traumatic } \\
\text { orthopedics, neurosurgery, dialysis (for patients with chronic kidney disease), } \\
\text { otology (for the treatment of diseases hearing aid). It also involves assistance in } \\
\text { restorative surgery (of mutilations, trauma or severe burns), bariatric surgery (in } \\
\text { cases of morbid obesity), reproductive surgery, assisted reproduction, clinical } \\
\text { genetics, nutritional therapy, progressive muscular dystrophy, imperfect } \\
\text { osteogenesis (genetic disease that causes bone fragility) and cystic fibrosis } \\
\text { (genetic disease that affects several organs of the body causing progressive } \\
\text { deficiencies). }\end{array}$ \\
\hline High complexity
\end{tabular}

Source: State Health Department ${ }^{20}$ 
The frequency of glycemic control depends on the degree of commitment pregnant, may initially be monitored every two weeks. In the case of pregnant women with pre-gestational diabetes, daily control should be performed. From 36 weeks onwards, control should be weekly. ${ }^{22}$.

In 2002, the National Pharmaceutical Assistance Program for Arterial Hypertension and Diabetes Mellitus was established, part of the Care Reorganization Plan based on the National Medicines Policy 4 . Hiperdia was also created, which is a system for registering and monitoring hypertensive and diabetic patients. Hiperdia's objective is to allow the monitoring of patients seen and registered in the outpatient network of the Brazilian Unified Health System (SUS) and to generate information for the acquisition, dispensation and distribution of medicines, in a systematic way, to these patients ${ }^{7}$.

Using the Hiperdia is possible to have a larger monitoring and thus prevention that can reduce significantly the mobimortalidade po GDM. According to the Ministry of Health ${ }^{21}$ and the Brazilian Diabetes Society ${ }^{16}$, prevention can be carried out by identifying individuals at risk (primary prevention), identifying undiagnosed cases (secondary prevention) and by treating individuals already affected by the disease, in order to prevent acute and chronic complications (tertiary prevention).

In this way, the importance of registering and monitoring pregnant women in the Hiperdia program is reaffirmed so that reports can be generated, enabling the knowledge of the situation and mapping the risks to enhance the attention to these people and minimize the conditioning factors of disease complications ${ }^{7}$.

It is vitally important to carry out glycemic control to improve the prognosis as early as possible, due to the deleterious effects of hyperglycemia on the pregnant woman and that consequently reaches the fetus through facilitated diffusion, generating an exaggerated production of insulin, which can cause several problems in relation to the fetus such as macrosomia, hypoglycemia, fetuses large for gestational age, intrauterine fetal death, among others. Since prenatal care must be followed, it is essential that each health service adopt a unique standard of diagnosis ${ }^{9,13}$. In the screening of GDM, anamnesis should be performed taking into account some criteria for the identification of risk factors, including:

- Hypertension or pre-eclampsia in the current pregnancy;

- Short stature (less than 4' 11 ");

- Family history of diabetes in first-degree relatives;

- Excessive central deposition of body fat;

- Age over 25 years;

- Obesity;

- Excessive weight gain in current pregnancy;

- Excessive fetal growth; and

- Polyhydramnios.

The screening should be performed at the first visit if the patient has risk factors to trigger the disease and all pregnant women between 24 and 28 weeks of gestationFasting plasma glucose measurement can be used for screening and diagnosis, and the association of fasting glucose with one or more risk factors is an alternative screening method ${ }^{23}$.

Currently, three methods of screening and diagnosing GDM are accepted (Table 2), one adopted by the American Diabetes Association (ADA) proposed by the National Diabetes Data Group, one by the World Health Organization (WHO) and a third by the Brazilian Society of Endocrinology and Metabology ${ }^{17}$.

The screening test or oral glucose tolerance test with 50 grams of glucose consists of determining blood glucose one hour after ingesting 50 grams of glucose at any time of the day. Values above $130 \mathrm{mg} / \mathrm{dL}$ are able to identify $90 \%$ of pregnant women with diabetes, and $140 \mathrm{mg} / \mathrm{dL}$ can identify $80 \%$. Blood glucose above $185 \mathrm{mg} / \mathrm{dL}$ is already a diagnosis of GDM. It is not necessary to carry out the screening test when the fasting blood glucose value is greater or equal to $126 \mathrm{mg} / \mathrm{dL}$ or $200 \mathrm{mg} / \mathrm{dL}$, which are indicative of $\mathrm{GDM}^{2}$. 
Pregnant women who have a plasma glucose equal to or above the values mentioned, are at high risk of developing glucose intolerance and must undergo a Glucose Tolerance Test (GTT). If the result is less than $140 \mathrm{mg} / \mathrm{dL}$, the test must be repeated between the 24th and 28th weeks and the 32 nd week $^{19}$.
Diagnostic confirmation can be performed through the Oral Glucose Tolerance Test (OGTT), usually the amount of glucose administered (75 or $100 \mathrm{~g}$ ) varies over two or three hours. The criteria adopted by the ADA and WHO for positivity establish confirmation of the GDM for blood glucose above two or more values presented $^{15}$.

Table 2. Positivity criteria for the screening and diagnosis of Gestational Diabetes Mellitus (GDM)

\begin{tabular}{|l|l|l|l|l|}
\multirow{2}{*}{ Tempo/ Testes } & Tracking & \multicolumn{4}{l}{ Diagnosis } \\
\cline { 2 - 5 } & $\begin{array}{l}\text { Fasting blood glucose + Risk } \\
\text { factors - OGTT } 50 \mathrm{~g}\end{array}$ & ADA $100 \mathrm{~g}$ & ADA $75 \mathrm{~g}$ & OMS $75 \mathrm{~g}$ \\
\hline Fasting & $126 \mathrm{mg} / \mathrm{dL}$ & $95 \mathrm{mg} / \mathrm{dL}$ & $95 \mathrm{mg} / \mathrm{dL}$ & $126 \mathrm{mg} / \mathrm{dL}$ \\
\hline $1 \mathrm{~h}$ & $130-140 \mathrm{mg} / \mathrm{dL}$ & $180 \mathrm{mg} / \mathrm{dL}$ & $180 \mathrm{mg} / \mathrm{dL}$ & \\
\hline $2 \mathrm{~h}$ & & $155 \mathrm{mg} / \mathrm{dL}$ & $155 \mathrm{mg} / \mathrm{dL}$ & $140 \mathrm{mg} / \mathrm{dL}$ \\
\hline $3 \mathrm{~h}$ & & $140 \mathrm{mg} / \mathrm{dL}$ & & \\
\hline
\end{tabular}

adapted from Reis ${ }^{26}$.

The ADA recommends using the OGTT with 100 $\mathrm{g}$ of glucose, including using the $75 \mathrm{~g}$ test, in this case, using only three glycemic values. In Brazil, the Diabetes and Pregnancy Working Groups together with the Brazilian Diabetes Association recommend the use of $75 \mathrm{~g}$ with fasting plasma measurements and in two hours, according to WHO criteria, which considers diagnostic criteria for both pregnant women and non-pregnant women ${ }^{11}$.

\section{Conclusion}

The various levels of complexity that the Brazilian Single Health System has allows an adequate therapeutic for the pathological conditions that the pregnant woman diagnosed with Gestational Diabetes Mellitus may present. Thus, the understanding of the complex levels of complexity enables the clinical adequacy on the part of those responsible for the treatment, as well as on the part of the pregnant woman.

\section{References}

1. American Diabetes Association. Gestational Diabetes Mellitus. Diabetes Care. 2004 Jan;27 Suppl 1:S88-S90.
2. Ayach, W.; Calderon, I. M. P.; Rudge, M. V. C.; Costa, R. A. A. Comparação entre dois testes de rastreamento do diabetes gestacional e o resultado perinatal. Revista Brasileira de Ginecologia e Obstetrícia. V. 32, n 5, p. 222-228, 2010.

3. Banckoja, M. B., Beydoun, A., Edwards, K. R., Schwartz, S. L., Fonseca, V., Hes, M. Endocrinologia e metabologia - complicações neuropáticas em diabetes mellitus; 1998.

4. BrasiL. Ministério da Saúde. Portaria no 371/GM de 04 mar. 2002. Referente à instituição do Programa Nacional de Assistência Farmacêutica para Hipertensão Arterial e Diabetes Mellitus, 2002.

5. Brasil. Ministério da Saúde. Programa de humanização do pré-natal e nascimento. Brasília: Secretaria de Políticas de Saúde; 2000.

6. Dode Maso, Santos IS. Fatores de risco para diabetes mellitus gestacional na coorte de nascimentos de Pelotas, Rio Grande do Sul, Brasil, 2004. Cad Saude Publica. 2009 mai;25(5):1141-52.

7. Ferreira, Celma Lúcia Rocha Alves, and Márcia Gonçalves Ferreira. "Características epidemiológicas de pacientes diabéticos da rede pública de saúde: análise a partir do sistema HiperDia." Arquivos Brasileiros de Endocrinologia \& Metabologia 53.1 (2009): 80-86. 
8. International Association of Diabetes and Pregnancy Study Groups. Recommendations on diagnosis and classification of hyperglycemia in pregnancy. Diabetes Care. 2010 Mar;33(3):67682.

9. Katz, L.; Amorim, M.; Coutinho. I.; Santos, L. C. Análise comparativa de testes diagnósticos para diabetes gestacional. Revista Brasileira de Ginecologia e Obstetrícia, v. 24, n. 8, p. 527-533, 2002.

10. Landim CAP, Milomens KMP, Diógenes MAR. Déficits de autocuidado em clientes com diabetes mellitus gestacional: uma contribuição para a enfermagem. Rev Gaúcha Enferm., Porto Alegre (RS) 2008 set;29(3):374-81

11. Macedo, G.; Caldas, G.; Griz, L.; Faria, M. S. Endocrinologia e Diabetes. Ed. Medsi. 2003, p. 883-889.

12. Manual Técnico. Ministério da saúde. Gestação de alto risco. Ed. 5a . Brasília-DF: Editora. MS. 2010. P. 183-185.

13. Manual Técnico. Pré-natal e puerpério: Atenção qualificada e humanizada. Brasília -DF: n.5. 2006.

14. Massucatti LA, Pereira RAP, Maioli TU. Prevalência de diabetes gestacional em Unidades de Saúde Básica. Rev Enferm Atençao Saude. 2012;1(1):70-9.

15. Mattar, R., Zamarian, A. C. P., Caetano, A. C. R., Torloni, M. R., Negrato, C. A. Como deve ser o rastreamento e diagnóstico do diabetes mellitus gestacional? Femina. V. 39 , n. 1. Jan. 2011.

16. Ministério da Saúde (MS). Secretaria de Vigilância da Saúde. Secretaria de Atenção Básica. Instituto Nacional do Câncer. Inquérito Domici- liar sobre Comportamento de Risco e Morbidade Referida de Doenças e Agravos Não Transmissíveis; 2004.

17. Nogueira, A. I. Diabetes mellitus e gravidez. Rio de Janeiro: MEDSI, p. 465-468. 2001.

18. Pan-American Health Organization (PAHO). Emergency Medical Teams. [Internet] Emergency Preparedness and Disaster Relief 2016. Disponível em: http://www.paho.org/disasters/index.php.

19. Queirós, J.; Magalhães, A.; Medina, J. L. Diabetes gestacional: uma doença, duas gerações, vários problemas. Revista Portuguesa de Endocrinologia, Diabetes e Metabolismo. p. 1924. 2006.

20. Secretaria de Estado de Saúde. Acessado em 13 de maio de 2020.Disponível em: https://www.saude.mg.gov.br/sus.

21. Sociedade Brasileira de Diabetes (SBD). Tratamento e acompanha- mento do diabetes mellitus. Diretrizes da Sociedade Brasileira de Dia- betes; 2006.

22. Stright, B.R.; Harrison, L.O. Enfermagem Materna e Neonatal. Série de Estudos em Enfermagem. 2 ed. Rio de Janeiro: Guanabara koogan, 1998. P. 80-81.

23. Tombini, M. Guia completo sobre Diabetes da (ADA) American Diabetes Association. Rio de Janeiro: Anima., 2002. p. 44-45-340-341.

24. Valladares CG, Komka SB. Prevalência de diabetes mellitus gestacional em gestantes de um centro de saúde de Brasília-DF. Comun Cienc Saude. 2008 jan- mar;19(1):11-7.

25. Reis, M. P. Diabetes mellitus gestacional. Associação Médica Brasileira e Conselho Federal de Medicina. 2006. 